\title{
Communication
}

\section{Revealing Tropical Technosols as an Alternative for Mine Reclamation and Waste Management}

\author{
Francisco Ruiz ${ }^{1}$, Fabio Perlatti ${ }^{1,2, *}$, Daniel P. Oliveira ${ }^{3}$ and Tiago O. Ferreira ${ }^{1}$ \\ 1 Soil Science Department, Luiz de Queiroz College of Agriculture, University of São Paulo (ESALQ/USP), Av. \\ Pádua Dias 11, Piracicaba, São Paulo 13418-900, Brazil; francisco.ruiz@usp.br (F.B.); toferreira@usp.br (T.O.F.) \\ 2 National Mining Agency-ANM, Rua Loefgren, 2225, São Paulo/SP 04040-033, Brazil \\ 3 Biology Department, Federal University of Ceará, Ac. Público 906, Fortaleza 60440-900, Ceará, Brazil; \\ dpo@alu.ufc.br \\ * Correspondence: fabio.perlatti@anm.gov.br
}

Received: 25 December 2019; Accepted: 14 January 2020; Published: 28 January 2020

\begin{abstract}
This study was based on the premise that Technosols constructed under tropical conditions are a valuable tool for inexpensive mine reclamation programs. These anthropogenic soils are still poorly studied in Brazil and are not recognized by the Brazilian Soil Classification System. Given the importance of mining to the Brazilian economy (the sector accounts for $20 \%$ of all products exported and $5 \%$ of the gross domestic product), there is an urgency to properly manage the large amount of waste produced. For this purpose, we suggest the use of Technosols as a strategy to overcome both land degradation and waste production by presenting a successful case of mine rehabilitation combining limestone wastes and tropical grasses. We show that Technosols constructed from the mine spoils can develop into soils suitable for agriculture in a few years, promoting land reclamation and producing food and energy. These soils are also valuable resources that can provide important ecosystem services, such as organic carbon storage.
\end{abstract}

Keywords: abandoned mine; constructed soils; land use; ecosystem services; organic carbon

\section{Introduction}

Among the most harmful anthropic activities to natural landscapes, mining stands out for causing large-scale ecosystem degradation [1,2]. Soil and water pollution, erosion, and deforestation are among some of the impacts caused by mining operations [3-5]. In surface mining, the entire regolith and the overlying rocks are removed for ore exploration, producing deep open-pits and leaving degraded landscapes commonly unsuitable for natural regeneration [6]. The removal of soils and its deposition with the overburden generates large waste dams and piles of mine spoils [7] that represents serious socioenvironmental risks when they are not properly managed.

On a global scale, the amount of mine wastes generated annually matches the magnitude of all the sediments transported by the natural processes shaping the Earth's landscape [8]. As an example, according to a recent study of the Brazilian Institute of Applied Economic Research (IPEA), it is estimated that in the period from 2010 to 2030, more than 11 billion tons of mine wastes will be generated in Brazil alone [9]. Additionally, the technological advancement will make it possible to explore deposits with lower ore grades, increasing waste generation as a consequence [10].

Recently, Brazil drew attention from the international community [11-14] by staging two of the biggest mining disasters of the country involving mining wastes: The collapse of the "Fundão" iron-ore tailings dam located in the municipality of Mariana (5 November 2015) and the rupture of the tailing dam "B1" at the "Córrego do Feijão mine" (25 January 2019) in the municipality of Brumadinho. 
The Mariana and Brumadinho disasters are considered the largest environmental disasters in the Brazilian history $[15,16]$. Both caused the death of mine workers and citizens and the devastation of historical, cultural and natural capital $[17,18]$, evidencing the need of better planning for the management and disposal of tailings generated by mining. However, this type of problem is not a "privilege" of Brazil. Armstrong et al. [10] points out that in the last 20 years, the number of accidents with mining dams has doubled, also occurring in countries like Spain (e.g., Los Frailes) and Canada (e.g., Mt Polley).

Mining is an activity of major importance to the Brazilian economy. The country's mineral sector is responsible for $5 \%$ of the gross domestic product and accounts for $20 \%$ of all products exported [19]. Brazil hosts the world's second largest iron ore production and the world's major niobium reserve [20]. Data obtained from the National Register of Mining Dams of the National Mining Agency (ANM) [21] indicate that there are currently more than 100,000 areas under mineral survey, more than 30,000 active mines, and 817 tailing dams in Brazil, which store approximately 3.4 billion $\mathrm{m}^{3}$ of tailings. Along with waste piles, tailing dams are the main forms of waste disposal in the country.

Considering the high environmental, social, and economic risks that these waste storage facilities represent, it is imperative to search for more environmentally friendly alternatives to reclaim abandoned mines and to dispose and manage mining wastes. In this context, Technosols appear as an interesting strategy not only for a suitable destination of mine wastes, but also for the recovery of a key natural resource (i.e., soil), promoting revegetation and finally the reclamation of abandoned and exhausted mines.

\section{Why Technosols?}

Technosols are anthropogenic soils introduced by the World Reference Base for Soil Resources in 2006 (WRB-FAO) [22]. These soils are essentially developed from materials made, modified, or exposed by human activities that otherwise would not occur at the Earth's surface, known as artefacts, including waste from mining, industrial and urban activities, such as mine spoils, household wastes, construction debris, sludge, and ashes [23-26]. In some cases, Technosols can develop spontaneously from the artefacts (e.g., mine spoils free from pollutants, sediments and excavated rock) [27,28]. In other situations, Technosols are specific created by combining different wastes and tailings to solve specific environmental problems, such as heavy metal pollution and acid mine drainage [29,30]. If deeply based on pedological concepts, these constructed soils are able to solve intricate environmental issues.

Even though the technogenic parent materials may be diverse, the processes occurring in these soils may resemble those observed in natural soils [31]. When the parental artefacts are prone to alteration, an incipient topsoil can be developed in less than 50 years [32-34]. Therefore, in tropical environments, where weathering rates tend to be intense, the evolution of these soils may be even faster, favoring their use in the reclamation of mine degraded sites.

Although some countries have reported successful experiences in rehabilitating abandoned mines using Technosols [35-38], most of these researches were conducted in the temperate climate zone, mainly in Europe. One of the consequences of this research scenario is the disregard of the current Brazilian Soil Classification System (SiBCS) [39] for the Technosols, which remains unrecognized as a specific soil order. In this context, its use as an alternative strategy for waste disposal is compromised, since governmental regulatory agencies do not have scientific bases to define or authorize its use. Therefore, understanding how these soils are formed and assigning them a proper classification is pivotal to ensure better knowledge on its functioning, adequate management, and sustainable use.

By revealing these soils in the tropical environment, we hope to motivate further research on tropical Technosols as a new promising technique for the disposal and reuse of mining wastes and mine reclamation in Brazil and other tropical countries. This knowledge also may contribute to the update of the Brazilian Soil Classification System (SiBCS) and be useful as a scientific basis for regulatory and environmental agencies to permit and stimulate the use of constructed Technosols for solving 
two problems at once: The environmentally friendly disposal of mine wastes and the reclamation of abandoned mines.

In this study, we present a successful attempt of rehabilitating a degraded dolomitic limestone mine site using a Technosol constructed with the mine spoils and planted with tropical grasses.

\section{Materials and Methods}

The study site was located at a mine company in the city of Saltinho (Southeast region of Brazil; Figure 1). The region is an important dolomitic limestone mining center in the state of São Paulo, with an indicated reserve of more than four million tons [40]. Surface mining was carried out in open pits to exploit the limestone ore present in the Irati Formation (Assistência member). The limestone layers are intercalated with pyro-bituminous shales and black non-bituminous shales which, as the overlying rocks, are not used. The mine spoils are composed of all materials with no economic interest. These include the topsoil and the excavated rocks. The amount of waste generated is often abandoned in large piles and can exceed up to 13-times that of the exploited ore [41]. Therefore, the correct allocation of wastes in order to minimize environmental impacts is indispensable.

A

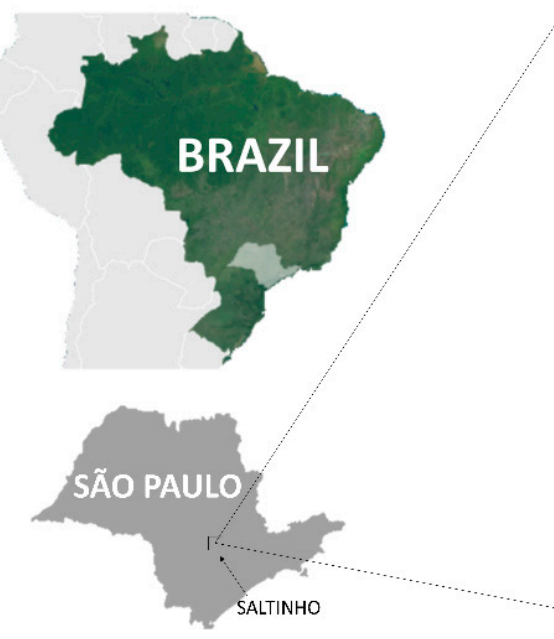

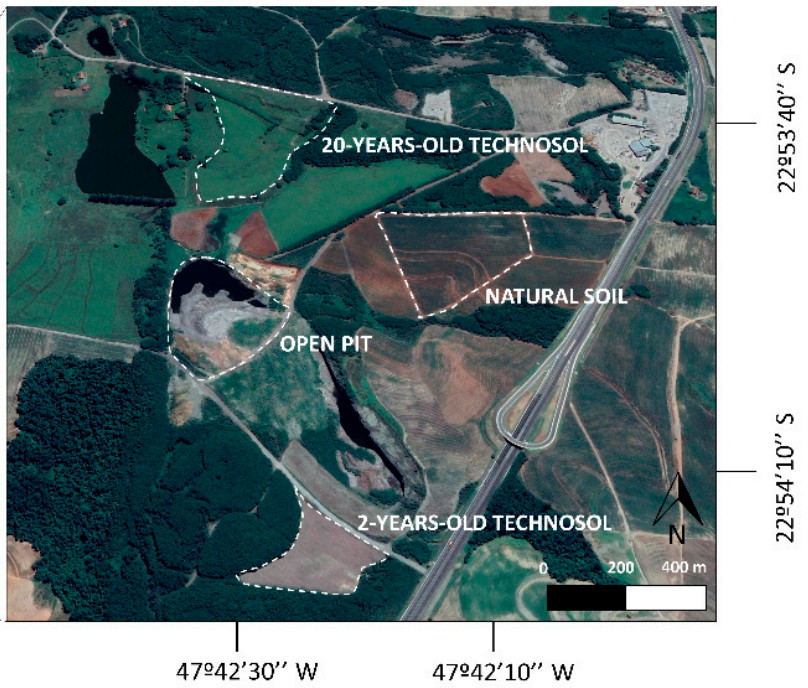

47을 $10^{\prime \prime} W$
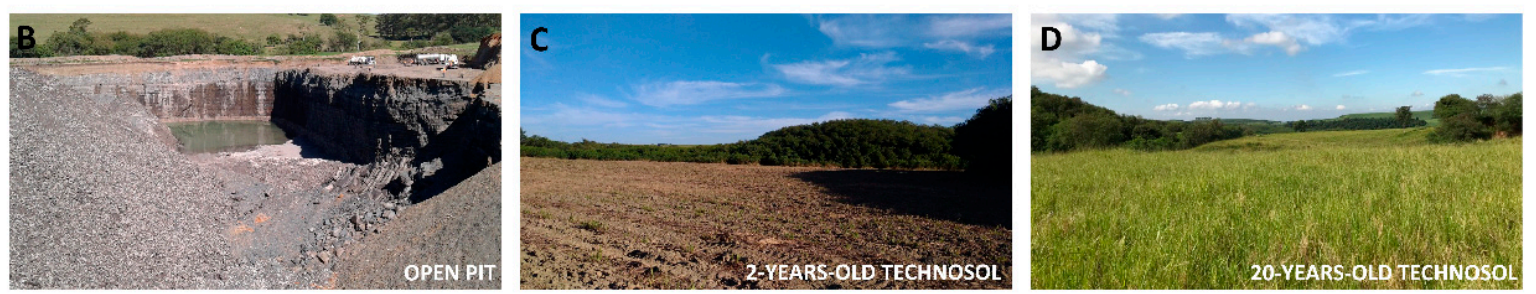

Figure 1. (A) Location of the study area in Saltinho, São Paulo State, Brazil, and distribution of the studied soils (image obtained on 21 May, 2018; Google ${ }^{\mathrm{TM}}$ Earth); (B) an open pit which is under rehabilitation; (C) Two-year-old Technosol grown with sugarcane; and (D) 20-year-old Technosol under pasture.

In this context, the limestone mining company started to rehabilitate exploited pits by constructing Technosols. The pits (approximately 25-m deep; see Figure 1B) were filled with the mine spoils. The artefacts (i.e., mine spoils) were mainly composed of Permian sedimentary rocks: Gray siltstones, black shales, and few dolomites fragments from Irati and Corumbataí Formations [42], which had been blasted and excavated, thus varying in size. No amendments or fertilizers were added during or after the rehabilitation process. When the pits were completely filled, the constructed soils were immediately destined to agriculture. 
We assessed the soil attributes of two Technosols: A 20-year-old Technosol under pasture and a two-year-old Technosol destined to sugarcane production. We also analyzed the chemical properties of a nearby natural soil cultivated with sugarcane as a basis of comparison. A soil pit was dug in each area for soil sampling and morphological description. Soil morphological attributes were described following the Guidelines for Soil Description [43] and the soils were classified according to the World Reference Base-FAO [44]. The $\mathrm{pH}$ was determined using a $\mathrm{pH}$ electrode in deionized water (soil: Solution ratio, 1:2,5). Exchangeable $\mathrm{Ca}^{2+}$ and $\mathrm{Mg}^{2+}$ were extracted with a $\mathrm{KCl} 1.0 \mathrm{~mol} \cdot \mathrm{L}^{-1}$ solution and determined by atomic absorption spectroscopy (Model 1100B, Bodenseewerk Perkin-Elmer GmbH, Alva, United Kindom). A Mehlich 1 solution was used to extract $\mathrm{K}^{+}, \mathrm{Na}^{+}$, and available P. The $\mathrm{K}^{+}$and $\mathrm{Na}^{+}$contents were determined by flame spectroscopy (Model DM-62, Digimed, São Paulo, Brazil), while available $\mathrm{P}$ content was measured by spectrophotometry. Potential acidity $(\mathrm{H}+\mathrm{Al})$ was measured by titration with $\mathrm{NaOH}$ after the extraction with calcium acetate $1.0 \mathrm{~mol} \cdot \mathrm{L}^{-1}$ at $\mathrm{pH}$ 7.0. Soil carbon was measured using an elemental analyzer (SSM-5000A, Shimadzu, Kyoto, Japan). The total inorganic carbon (TIC) was calculated as the difference between total soil carbon and total organic carbon (TOC), after the removal of inorganic carbon with $3 \mathrm{~mol} \cdot \mathrm{L}^{-1}$ of $\mathrm{HCl}$ solution [45].

To quantify and spatialize the areas containing limestone mining titles throughout the Brazilian territory, a georeferenced database was downloaded from the National Mining Agency of Brazil (Agência Nacional de Mineração-ANM) website [46]. The data was analyzed using the Qgis software (version 3.4.14 LTR, Qgis Development Team, Madeira, Portugal).

\section{Results and Discussion}

\subsection{Soil Attributes}

Regarding the morphological attributes, the two-year-old constructed soil, a Hyperskeletic Spolic Technosol (Clayic), presented a weak structure with the predominance of artefacts fragments (Figure 2D) in contrast to the older Technosol, a Hyperskeletic Spolic Technosol (Hyperhumic, Somerimollic), which showed a well-developed soil structure (Figure 2C,E), especially in the first $10 \mathrm{~cm}$. The soil structure of the latter was similar to those found in soils with a well-developed surface horizon, e.g., Mollisols. There was also evidence of color development when comparing the studied Technosols. The two-year-old Technosol exhibited dark gray colors (2.5Y 4/1), whereas the 20-year-old Technosol was dark brown (10YR 2.5/1) throughout the profile. The darkening of the soil profile was intimately related to the high amounts of soil organic carbon (SOC), which ranged from $7.7 \%$ to $10.1 \%$ at surface (Table 1).

Table 1. Chemical attributes of topsoil of the studied Technosols and the natural soil.

\begin{tabular}{|c|c|c|c|c|c|c|c|c|c|c|}
\hline Depth $(\mathrm{cm})$ & $\mathrm{pH}$ & TOC $^{1}$ & $\mathrm{Na}^{+}$ & $\mathrm{K}^{+}$ & $\mathrm{Ca}^{2+}$ & $\mathrm{Mg}^{2+}$ & $\mathrm{H}^{+}+\mathrm{Al}^{3+}$ & $\mathbf{P}$ & $\mathrm{CEC}^{2}(\mathrm{pH} 7.0)$ & Base sat. $^{3}$ \\
\hline & & $\%$ & & & \multicolumn{2}{|c|}{$\mathrm{cmol}_{\mathrm{C}} \cdot \mathrm{kg}^{-1}$} & & $\mathrm{mg} \cdot \mathrm{kg}^{-1}$ & $\mathrm{cmol}_{\mathrm{C}} \cdot \mathrm{kg}^{-1}$ & $\%$ \\
\hline \multicolumn{11}{|c|}{ Two-year-old: Hyperskeletic Spolic Technosol (Clayic) } \\
\hline 0-10 & 7.1 & 0.7 & 0.2 & 0.3 & 10.0 & 12.5 & 2.1 & 129.9 & 25.1 & 91.6 \\
\hline 10-20 & 7.2 & 0.4 & 0.5 & 0.3 & 9.8 & 12.1 & 2.1 & 120.1 & 24.8 & 91.4 \\
\hline $20-30$ & 7.6 & 0.5 & 0.8 & 0.2 & 10.1 & 15.1 & 2.1 & 100.5 & 28.3 & 92.5 \\
\hline \multicolumn{11}{|c|}{ 20-year-old: Hyperskeletic Spolic Technosol (Somerimollic, Hyperhumic) } \\
\hline 0-10 & 7.2 & 10.1 & 0.2 & 0.5 & 16.9 & 16.4 & 2.2 & 42.4 & 36.2 & 93.9 \\
\hline $10-20$ & 7.2 & 7.7 & 0.3 & 0.3 & 18.1 & 14.9 & 2.2 & 51.2 & 35.8 & 93.8 \\
\hline $20-30$ & 7.3 & 7.7 & 0.2 & 0.3 & 16.5 & 11.6 & 2.3 & 57.5 & 30.9 & 92.6 \\
\hline \multicolumn{11}{|c|}{ Natural Soil: Rhodic Lixisol } \\
\hline 0-10 & 7.0 & 1.9 & $<0.1$ & $<0.1$ & 7.8 & 6.5 & 2.5 & 3.9 & 16.9 & 85.3 \\
\hline $10-20$ & 6.9 & 1.6 & $<0.1$ & $<0.1$ & 8.7 & 5.4 & 3.3 & 3.2 & 17.5 & 81.0 \\
\hline $20-30$ & 6.7 & 1.4 & $<0.1$ & $<0.1$ & 8.3 & 4.9 & 2.9 & 1.8 & 16.2 & 82.0 \\
\hline
\end{tabular}



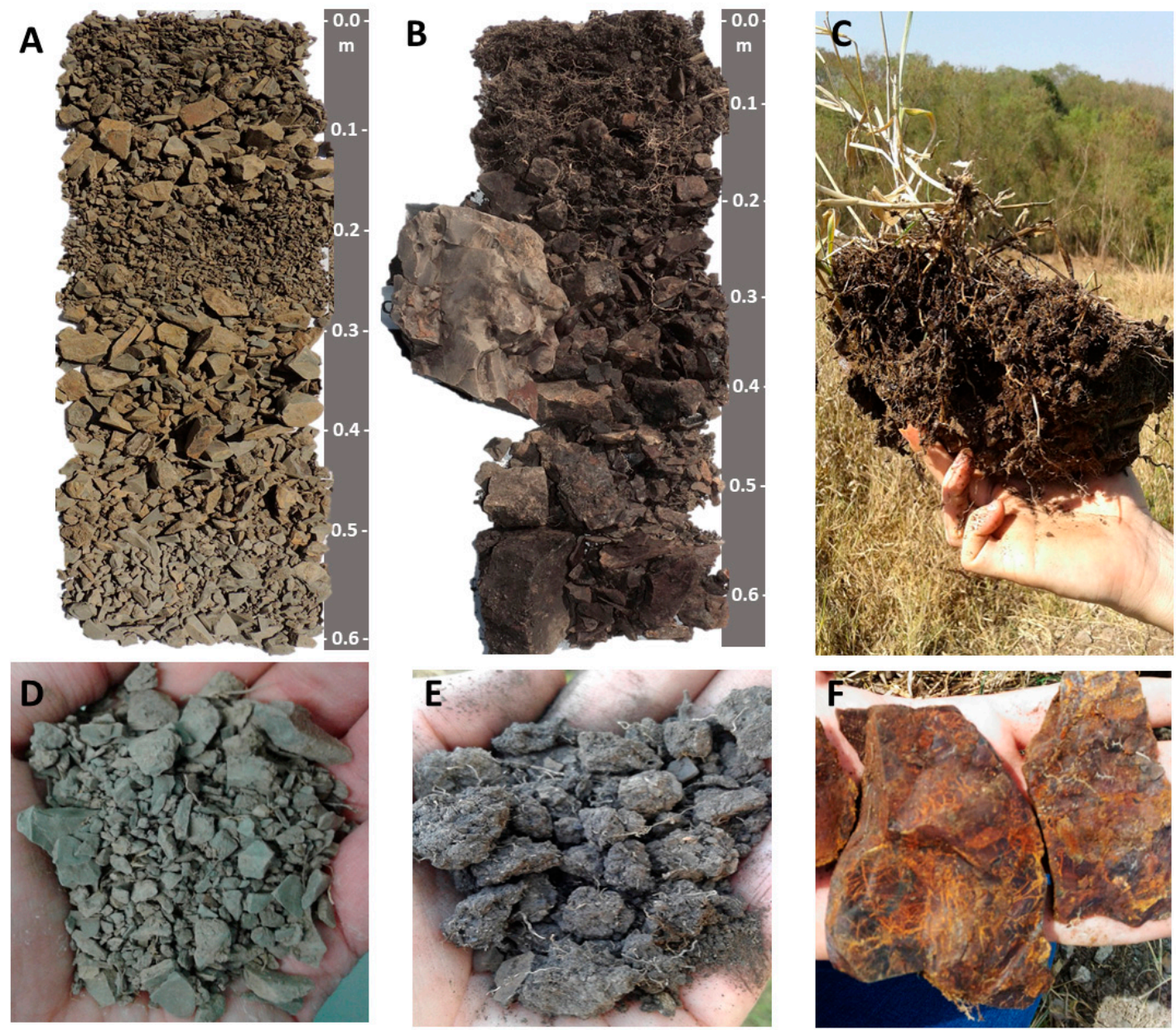

Figure 2. (A) Two year-old Technosol soil profile; (B) 20 year-old Technosol soil profile; (C) Soil structure produced by the high root density and activity; (D) Weakly developed soil structure in the two-year-old Technosol; (E) Well-developed structure from the surface horizon of the 20-year-old Technosol; (F) Altered artefacts (black shale): Oxidation and fragmentation induced by root growth between the shale laminations.

The build-up of TOC toward the soil surface in the 20-year-old Technosol suggests that the decomposition of grass roots was the main input of organic matter in this soil. The high root density (Figure 2C) and organic matter content provided by the forage grasses were responsible for the strong soil aggregation. Aggregates size and stability are directly related to the ability of a soil to resist erosion processes [47] and are especially important in tropical soils since they are more susceptible to rainfall erosion [48]. Besides increasing SOC content and promoting soil aggregation, root growth within the artefacts (Figure 2F) was important to the fragmentation of the deposited artifacts and the speeding up of several chemical alterations (e.g., oxidation, carbonate dissolution and clay formation).

The chemical attributes of topsoil (Table 1) show that both Technosols were suitable for plant development. The fertility of the Technosols was equivalent or even higher than that of the natural soils in the surroundings. Soil $\mathrm{pH}$ values were near neutral and nutrients availability, and calcium (Ca), magnesium $(\mathrm{Mg})$, and phosphorous $(\mathrm{P})$ were higher for the constructed soils than for the natural soil (Rhodic Lixisol). Particularly phosphorous, which is the most limiting plant nutrient in tropical soils [49], was approximately 40-times higher in the youngest Technosol than in the natural soil. The cation exchange capacity (CEC) was also higher for Technosols and was occupied mainly by $\mathrm{Ca}^{2+}$ and $\mathrm{Mg}^{2+}$, probably due to the dissolution of carbonates from the artefacts. The high content of organic carbon (up to $10.1 \%$ at $0-10 \mathrm{~cm}$ depth) in the 20-year-old Technosol was particularly important 
as nutrients are easily leached in tropical soils, so these must rely on the recycling of nutrients from organic matter to sustain its fertility [50].

Whereas the soil formation rate of natural soils is slow (estimated $0.0056 \mathrm{~cm} \cdot \mathrm{year}^{-1}$ [51]), these tropical Technosols seem to be evolving at a high rate into soils suitable for plant growth. Also, compared to Technosols developing from similar artefacts (mine spoils) in temperate zones [27,52-54], the studied soil exhibited a more advanced profile evolution. The higher rate of soil formation is also particularly beneficial for the crops since mine spoils can continuously release plant nutrients during alteration. Moreover, particular attention must be given to the ability of the 20-year-old Technosol to store SOC. The mean TOC value for the $0-30 \mathrm{~cm}$ topsoil reached $8.5 \%$, which was at least five-times higher than the carbon content in the natural soil $(=1.6 \%)$ and the average SOC in Brazilian soils $(=1.72 \%$ [55]) for the same depth. This highlights the remarkable potential of using Technosols as allies against climate change.

\subsection{Potential Environmental and Economic Benefits of Technosols}

Soil valuation and ecosystem services are increasingly emphasized in the context of natural resources management. Besides providing human's basic needs like food, fiber, and energy, soils are responsible for critical contributions to society as they deliver important goods and services, such as climate regulation, nutrient recycling, water infiltration, and provision of antibiotics and new organisms used in medicine [56-58]. Thus, soil losses represent an important environmental and economic drawback.

Among soil degradation processes, erosion is the more commonly assessed aspect from a cost valuation point of view [59] and has plagued civilization for centuries [60]. Open pit mining can be understood as a human-caused erosion that results in the complete loss of soil. The compiled data from the cadastral system of the National Mining Agency [61], which encompasses all mining areas in the country, indicates that there are 159 active limestone mining sites in the state of São Paulo alone, corresponding to an area of $209 \mathrm{~km}^{2}$ (Table S1). Assessing the whole Brazilian territory, the total area granted to limestone ore exploration reaches $27,129 \mathrm{~km}^{2}$, which is about the extension of the Belgian territory (Figure 3, Table S2). If we consider the $0-30 \mathrm{~cm}$ topsoil and an average soil bulk density of $1.3 \mathrm{~g} \cdot \mathrm{cm}^{-3}$, the exploration of all those mining titles would be equivalent to the loss of 10.6 billion tons of soil by erosion. 


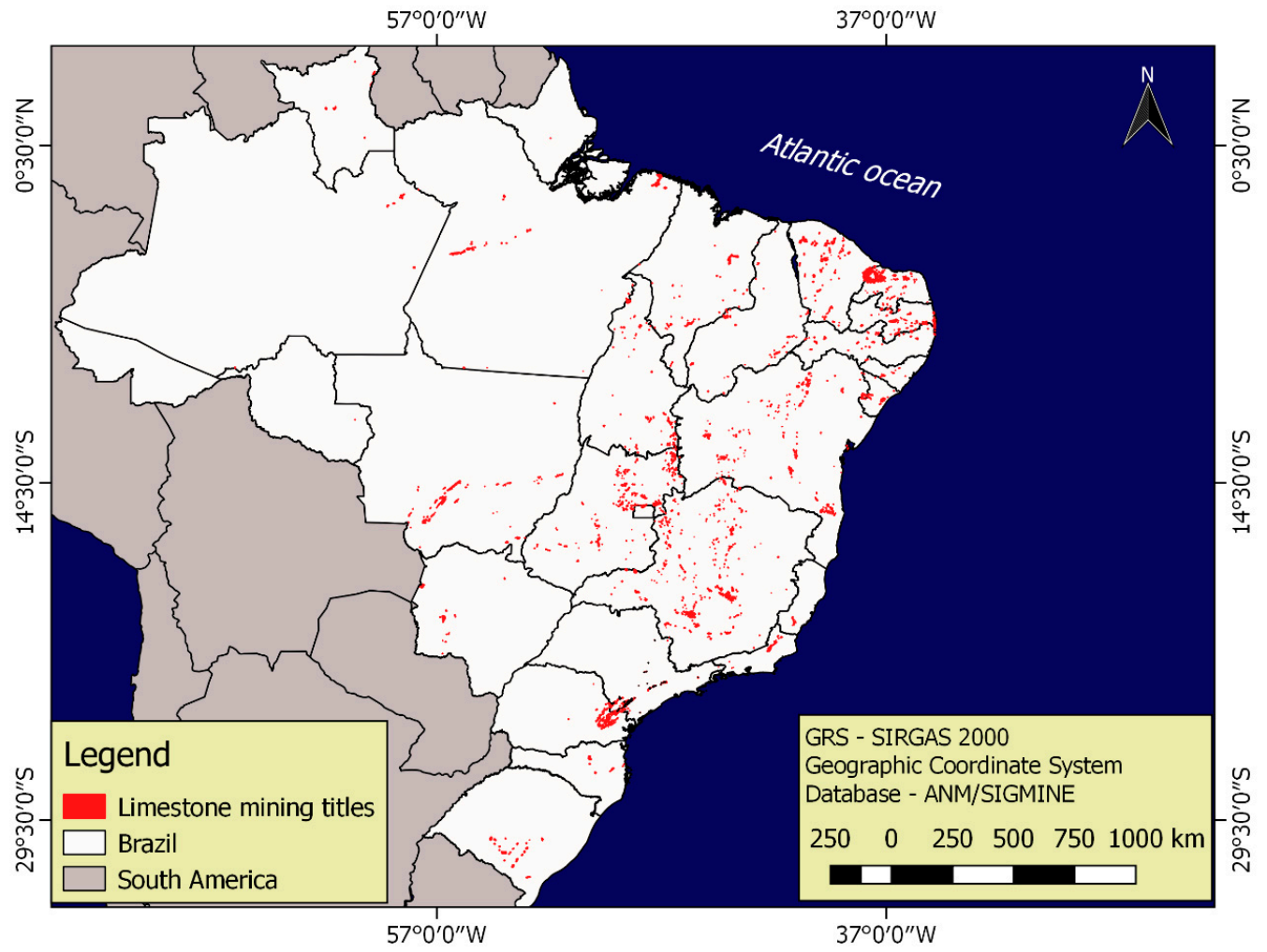

Figure 3. Distribution of limestone mining titles throughout the Brazilian territory, covering an area of $27,129 \mathrm{~km}^{2}$.

Robinson [59] calculated the costs of major elements for the reconstitution of topsoil. He estimated that the replacement of mineral components (sand, silt, and clay), carbon, and macronutrients (NPK) would cost about $94,632 \mathrm{USD}$ for the $30 \mathrm{~cm}$ of topsoil/ha, not accounting for the transport, mixing, and time required for soil formation. That would be the equivalent of expending 256 billion USD to restore the topsoil of all the limestone mining title areas in Brazil.

In contrast, the mining company in Saltinho successfully created an arable land in 20 years with basically no cost, except for machinery operations. Moreover, the constructed Technosols were not only suitable for plant development, but also presented high potential to provide ecosystem services, especially climate regulation by promoting carbon storage.

It would be mistaken, though, to affirm that any mine waste could directly return to the explored pit and create a healthy environment for plant growth. Several mine spoils and tailings contain potential pollutants for soil and water resources [62-65]. Still, in these cases, Technosols continue to be a very promising tool for mine land reclamation. A number of studies have been conducted on combining potential harmful mine wastes with different types of residues, amendments, and plants, to minimize their hazardous effect [66-69]. In soil science, most of the studies on soil functions and ecosystem services have been restricted to natural soils. Now, focus must be placed on the recognition of ecosystem services provided by artificial soils in which Technosols are included.

\section{Conclusions}

The present work shows that the construction of Technosols using mine spoils can promote a favorable environment for plant growth, evidencing its high potential as an alternative for the rehabilitation of abandoned mines, where natural soils were completely lost. Our data suggest that under tropical conditions, Technosols constructed with limestone mine spoils can evolve into fertile soils in few years. In fact, the fertility of the Technosol under pasture surpassed that of the nearby 
natural soil after 20 years of soil development. Thus, the construction of Technosols is a low-cost strategy for both waste management and land reclamation.

Due to the diversity of mine spoils and tailings, there are many possibilities to explore different combinations of wastes and plants that can result in different soils with unique properties and abilities to provide ecosystem services. This reveals countless possibilities for the assemblage of Technosols capable of overcoming complex environmental problems. The proper recognition of Technosols as a soil order in the Brazilian Soil Classification System (SiBCS) is also an important step to propagate this mine land reclamation technique to policymakers. The scientific divulgation is essential to encourage further studies that could foment the use of Technosols in national mine soil reclamation programs, providing more information to support its management and sustainable use. Moreover, highlighting the potential of reclaimed soils for provision of goods and services may increase the range of land use intended to energy and food production.

Supplementary Materials: The following are available online at http://www.mdpi.com/2075-163X/10/2/110/s1, Table S1: Limestone mining area of the State of São Paulo; Table S2: Limestone mining titles of the whole Brazilian territory, divided into federative unities.

Author Contributions: Conceptualization, F.R., T.O.F. and F.P.; soil description, sampling and analyses, F.R.; data gathering, D.P.O. and F.P.; Map designing, D.P.O.; Writing, all authors. All authors have read and agreed to the published version of the manuscript.

Funding: This study was funded by the Coordination for the Improvement of Higher Education Personnel - Brazil (CAPES)- Finance code 001 and the National Council for Scientific and Technology Development (CNPq, process 308288/2014-9).

Acknowledgments: The authors wish to thank the limestone mine company "Calcário Amaral Machado" and especially the mining engineer Marcelo Lopes Dall Antonia for granting information about the study area.

Conflicts of Interest: The authors declare no conflict of interest.

\section{References}

1. Bradshaw, A. Restoration of mined lands-Using natural processes. Ecol. Eng. 1997, 8, 255-269. [CrossRef]

2. Lima, A.T.; Mitchell, K.; O'Connell, D.W.; Verhoeven, J.; Van Cappellen, P. The legacy of surface mining: Remediation, restoration, reclamation and rehabilitation. Environ. Sci. Policy 2016, 66, 227-233. [CrossRef]

3. Robles-Arenas, V.M.; Rodríguez, R.; García, C.; Manteca, J.I.; Candela, L. Sulphide-mining impacts in the physical environment: Sierra de Cartagena-La Unión (SE Spain) case study. Environ. Geol. 2006, 51, 47-64. [CrossRef]

4. Swenson, J.J.; Carter, C.E.; Domec, J.-C.; Delgado, C.I. Gold mining in the Peruvian Amazon: Global prices, deforestation, and mercury imports. PLoS ONE 2011, 6, e18875. [CrossRef] [PubMed]

5. Thornton, E.B.; Sallenger, A.; Sesto, J.C.; Egley, L.; McGee, T.; Parsons, R. Sand mining impacts on long-term dune erosion in southern Monterey Bay. Mar. Geol. 2006, 229, 45-58. [CrossRef]

6. Szabó, J. Anthropogenic geomorphology: subject and system. In Anthropogenic Geomorphology: A Guide to Man-Made Landforms; Szabó, J., Dávid, L., Lóczy, D., Eds.; Springer: Dordrecht, The Netherlands, 2010; pp. 3-10. ISBN 978-90-481-3058-0.

7. Lottermoser, B. Introduction to mine wastes. In Mine Wastes: Characterization, Treament and Environmental Impacts, 2nd ed.; Lottermoser, B., Ed.; Springer-Verlag: Heidelberg/Berlin, Germany, 2007; pp. 1-41.

8. Kossoff, D.; Dubbin, W.E.; Alfredsson, M.; Edwards, S.J.; Macklin, M.G.; Hudson-edwards, K.A. Applied geochemistry mine tailings dams: Characteristics, failure, environmental impacts, and remediation. Appl. Geochem. 2014, 51, 229-245. [CrossRef]

9. IPEA-Instituto de pesquisa aplicada. Diagnóstico dos Resíduos Sólidos da Atividade de Mineração de Substâncias Não Energéticas; Plano Nacional de Resíduos Sólidos (PNRS), Ministério do Meio Ambiente: Brasília, Brazil, 2012.

10. Armstrong, M.; Petter, R.; Petter, C. Why have so many tailings dams failed in recent years? Resour. Policy 2019, 63, 101412. [CrossRef] 
11. Phillips, D. Samarco dam collapse: One year on from Brazil's worst environmental disaster. The Guardian. Available online: https://www.theguardian.com/sustainable-business/2016/oct/15/samarco-dam-collapsebrazil-worst-environmental-disaster-bhp-billiton-vale-mining (accessed on 2 December 2019).

12. Carneiro, J.D. Brazil dam burst: Six months on, the marks left by sea of sludge. British Broadcasting Corporation. Available online: https://www.bbc.com/news/world-latin-america-36230578 (accessed on 2 December 2019).

13. De Sá, G. Brazil's deadly dam disaster may have been preventable. National Geographic. Available online: https://www.nationalgeographic.com/environment/2019/01/brazil-brumadinho-mine-tailings-damdisaster-could-have-been-avoided-say-environmentalists/ (accessed on 2 December 2019).

14. Darlington, S.; Glanz, J.; Andreoni, M.; Bloch, M.; Peçanha, S.; Singhvi, A.; Griggs, T. A tidal wave of mud. The New York Times. Available online: https:/www.nytimes.com/interactive/2019/02/09/world/americas/ brazil-dam-collapse.html (accessed on 2 December 2019).

15. Do Carmo, F.F.; Kamino, L.H.Y.; Junior, R.T.; de Campos, I.C.; do Carmo, F.F.; Silvino, G.; Mauro, M.L.; Rodrigues, N.U.A.; de Souza Miranda, M.P.; Pinto, C.E.F. Fundão tailings dam failures: The environment tragedy of the largest technological disaster of Brazilian mining in global context. Perspect. Ecol. Conserv. 2017, 15, 145-151. [CrossRef]

16. Thompson, F.; de Oliveira, B.C.; Cordeiro, M.C.; Masi, B.P.; Rangel, T.P.; Paz, P.; Freitas, T.; Lopes, G.; Silva, B.S.; Cabral, A.S.; et al. Severe impacts of the Brumadinho dam failure (Minas Gerais, Brazil) on the water quality of the Paraopeba River. Sci. Total Environ. 2020, 705, 135914. [CrossRef]

17. Fernandes, G.W.; Goulart, F.F.; Ranieri, B.D.; Coelho, M.S.; Dales, K.; Boesche, N.; Bustamante, M.; Carvalho, F.A.; Carvalho, D.C.; Dirzo, R.; et al. Deep into the mud: ecological and socio-economic impacts of the dam breach in Mariana, Brazil. Nat. Conserv. 2016, 14, 35-45. [CrossRef]

18. Queiroz, H.M.; Nóbrega, G.N.; Ferreira, T.O.; Almeida, L.S.; Romero, T.B.; Santaella, S.T.; Bernardino, A.F.; Otero, X.L. The Samarco mine tailing disaster: A possible time-bomb for heavy metals contamination? Sci. Total Environ. 2018, 637, 498-506. [CrossRef] [PubMed]

19. MME-Ministério de Minas e Energia. Boletim Informativo do Setor Mineral 2018. Available online: http://www.mme.gov.br/documents/36108/406012/Boletim+Informativo+do+Setor+Mineral+2018+ -+English+Version.pdf/67707fd3-fd82-9e87-c9ca-86fadff93be0 (accessed on 5 December 2019).

20. USGS-U.S. Geological Survey. Mineral Commodity Summaries. Available online: https://www.usgs.gov/ centers/nmic/mineral-commodity-summaries (accessed on 5 December 2019).

21. ANM-Agência Nacional de Mineração. Classificação das Barragens de Mineração - database 02/2019. Available online: http://www.anm.gov.br/assuntos/barragens/pasta-cadastro-nacional-de-barragens-demineracao/cadastro-nacional-de-barragens-de-mineracao (accessed on 5 December 2019).

22. IUSS Working Group WRB. World Reference Base for Soil Resources 2006: A Framework for International Classification, Correlation and Communication; World Soil Resources Reports No. 103; FAO: Rome, Italy, 2006; Available online: http://www.fao.org/3/a-a0510e.pdf (accessed on 15 January 2020).

23. Huot, H.; Faure, P.; Biache, C.; Lorgeoux, C.; Simonnot, M.-O.; Morel, J.L. A Technosol as archives of organic matter related to past industrial activities. Sci. Total Environ. 2014, 487, 389-398. [CrossRef] [PubMed]

24. Krechetov, P.; Chernitsova, O.; Sharapova, A.; Terskaya, E. Technogenic geochemical evolution of chernozems in the sulfur coal mining areas. J. Soils Sediments 2018, 19, 3139-3154. [CrossRef]

25. Rokia, S.; Séré, G.; Schwartz, C.; Deeb, M.; Fournier, F.; Nehls, T.; Damas, O.; Vidal-Beaudet, L. Modelling agronomic properties of Technosols constructed with urban wastes. Waste Manag. 2014, 34, 2155-2162. [CrossRef] [PubMed]

26. Villenave, C.; Séré, G.; Schwartz, C.; Watteau, F.; Jimenez, A.; Cortet, J. Rapid changes in soil nematodes in the first years after technosol construction for the remediation of an industrial wasteland. Eurasian Soil Sci. 2018, 51, 1266-1273. [CrossRef]

27. Scholtus, N.; Echevarria, G.; Florentin, L.; Bonis, M.L.; De, P.; Simonnot, M.O.; Morel, J.L. Expected evolution of a Technosol derived from excavated Callovo-Oxfordian clay material. J. Soils Sediments 2014, 15, 332-346. [CrossRef]

28. Santini, T.C.; Fey, M.V. Assessment of Technosol formation and in situ remediation in capped alkaline tailings. Catena 2016, 136, 17-29. [CrossRef] 
29. Asensio, V.; Flórido, F.G.; Ruiz, F.; Perlatti, F.; Otero, X.L.; Oliveira, D.P.; Ferreira, T.O. The potential of a Technosol and tropical native trees for reclamation of copper-polluted soils. Chemosphere 2019, 220, 892-899. [CrossRef]

30. Rodríguez-Vila, A.; Forján, R.; Guedes, R.S.; Covelo, E.F. Nutrient phytoavailability in a mine soil amended with technosol and biochar and vegetated with Brassica juncea. J. Soils Sediments 2017, 17, 1653-1661. [CrossRef]

31. Huot, H.; Morel, J.L.; Simonnot, M.O. Pedogenetic trends in soils formed in technogenic materials. Soil Sci. 2015, 180, 182-192. [CrossRef]

32. Grünewald, G.; Kaiser, K.; Jahn, R. Alteration of secondary minerals along a time series in young alkaline soils derived from carbonatic wastes of soda production. Catena 2007, 71, 487-496. [CrossRef]

33. Howard, J.L.; Dubay, B.R.; Daniels, W.L. Artifact weathering, anthropogenic microparticles and lead contamination in urban soils at former demolition sites, Detroit, Michigan. Environ. Pollut. 2013, 179, 1-12. [CrossRef] [PubMed]

34. Hayes, S.M.; Root, R.A.; Perdrial, N.; Maier, R.M.; Chorover, J. Surficial weathering of iron sulfide mine tailings under semi-arid climate. Geochim. Cosmochim. Acta 2014, 141, 240-257. [CrossRef] [PubMed]

35. Almendro-Candel, M.B.; Navarro-Pedreño, J.; Jordán, M.M.; Gómez, I.; Meléndez-Pastor, I. Use of municipal solid waste compost to reclaim limestone quarries mine spoils as soil amendments: Effects on Cd and Ni. J. Geochem. Explor. 2014, 144, 363-366. [CrossRef]

36. Watkinson, A.D.; Lock, A.S.; Beckett, P.J.; Spiers, G. Developing manufactured soils from industrial by-products for use as growth substrates in mine reclamation. Restor. Ecol. 2017, 25, 587-594. [CrossRef]

37. Ahirwal, J.; Kumar, A.; Pietrzykowski, M.; Maiti, S.K. Reclamation of coal mine spoil and its effect on Technosol quality and carbon sequestration: A case study from India. Environ. Sci. Pollut. Res. 2018, 25, 27992-28003. [CrossRef]

38. Santos, E.S.; Abreu, M.M.; Macías, F. Rehabilitation of mining areas through integrated biotechnological approach: Technosols derived from organic/inorganic wastes and autochthonous plant development. Chemosphere 2019, 765-775. [CrossRef]

39. EMBRAPA-Empresa brasileira de pesquisa agropecuária. Sistema brasileiro de classificação de solos. Available online: http://ainfo.cnptia.embrapa.br/digital/bitstream/item/199517/1/SiBCS-2018-ISBN9788570358004.pdf (accessed on 15 January 2020).

40. DNPM-Departamento Nacional de Produção Mineral. Brazilian Mineral Yearbook 2010; DNPM: Brasília, Brazil, 2010.

41. Souza, M.H.O. Separação do calcario e do folhelo pirobetuminoso da formação Irati para a utilização como corretivo e como aditivo na indústria cerâmica. Ph.D. Thesis, São Paulo State University (UNESP), Rio Claro, Brazil, April 2013.

42. IPT-Institute for Technological Research. Geological Map of the State of São Paulo: Scale 1:500,000; IPT: São Paulo, Brazil, 1981; (IPT Monographs, 6, Publication, 1184).

43. Food and Agricultural Organization of the United Nations (FAO). Guidelines for Soil Description; Food and Agricultural Organization of the United Nations: Rome, Italy, 2006.

44. IUSS Working Group WRB. World Reference Base for Soil Resources 2014, Update 2015. International Soil Classification System for Naming Soils and Creating Legends for Soil Maps. 2014; World Soil Resources Reports No. 106; Food and Agricultural Organization of the United Nations: Rome, Italy, 2015.

45. Soil Survey Staff. Soil Survey Field and Laboratory Methods Manual; Soil Survey Investigations Report No. 51, Version 2.0. R; Burt and Soil Survey Staff, Ed.; U.S. Department of Agriculture: Washington, DC, USA, 2014.

46. ANM - Agência Nacional de Mineração. Sigmine. Available online: http://www.anm.gov.br/assuntos/aominerador/sigmine. (accessed on 17 January 2020).

47. Torri, D.; Ciampalini, R.; Gil, P.A. The Role of Soil Aggregates in Soil Erosion Processes. In Modelling Soil Erosion by Water; Boardman, J., Favis-Mortlock, D., Eds.; Springer Berlin Heidelberg: Berlin/Heidelberg, Germany, 1998; pp. 247-257.

48. Panagos, P.; Borrelli, P.; Meusburger, K.; Yu, B.; Klik, A.; Jae Lim, K.; Yang, J.E.; Ni, J.; Miao, C.; Chattopadhyay, N.; et al. Global rainfall erosivity assessment based on high-temporal resolution rainfall records. Sci. Rep. 2017, 7, 4175. [CrossRef]

49. Hou, E.; Tan, X.; Heenan, M.; Wen, D. A global dataset of plant available and unavailable phosphorus in natural soils derived by Hedley method. Sci. Data 2018, 5, 180166. [CrossRef] 
50. Tiessen, H.; Cuevas, E.; Chacon, P. The role of soil organic matter in sustaining soil fertility. Nature 1994, 371 , 783-785. [CrossRef]

51. Wakatsuki, T.; Rasyidin, A. Rates of weathering and soil formation. Geoderma 1992, 52, 251-263. [CrossRef]

52. Néel, C.; Bril, H.; Courtin-Nomade, A.; Dutreuil, J.P. Factors affecting natural development of soil on 35-year-old sulphide-rich mine tailings. Geoderma 2003, 111, 1-20. [CrossRef]

53. Sokolov, D.A.; Androkhanov, V.A.; Kulizhskii, S.P.; Domozhakova, E.A.; Loiko, S.V. Morphogenetic diagnostics of soil formation on tailing dumps of coal quarries in Siberia. Eurasian Soil Sci. 2015, 48, 95-105. [CrossRef]

54. Pellegrini, S.; García, G.; Peñas-Castejon, J.M.; Vignozzi, N.; Costantini, E.A.C. Pedogenesis in mine tails affects macroporosity, hydrological properties, and pollutant flow. Catena 2016, 136, 3-16. [CrossRef]

55. Gomes, L.C.; Faria, R.M.; de Souza, E.; Veloso, G.V.; Schaefer, C.E.G.R.; Filho, E.I.F. Modelling and mapping soil organic carbon stocks in Brazil. Geoderma 2019, 340, 337-350. [CrossRef]

56. Adhikari, K.; Hartemink, A.E. Linking soils to ecosystem services-A global review. Geoderma 2016, 262, 101-111. [CrossRef]

57. Baveye, P.C.; Baveye, J.; Gowdy, J. Soil “Ecosystem” Services and Natural Capital: Critical Appraisal of Research on Uncertain Ground. Front. Environ. Sci. 2016, 4, 41. [CrossRef]

58. Pereira, P.; Bogunovic, I.; Muñoz-Rojas, M.; Brevik, E.C. Soil ecosystem services, sustainability, valuation and management. Curr. Opin. Environ. Sci. Health 2018, 5, 7-13. [CrossRef]

59. Robinson, D.; Fraser, I.; Dominati, E.; Davidsdottir, B.; Jónsson, J.; Jones, L.; Jones, S.; Tuller, M.; Lebron, I.; Bristow, K.; et al. On the Value of Soil Resources in the Context of Natural Capital and Ecosystem Service Delivery. Soil Sci. Soc. Am. J. 2014, 78, 685-700. [CrossRef]

60. Winiwarter, V.; Mcneill, J. Breaking the Sod. Humankind, History and Soil. Science 2004, 304, 1627-1629.

61. ANM-Agência Nacional de Mineração. Cadastro Mineiro 2019. Available online: https://sistemas.dnpm. gov.br/SCM/extra/site/admin/Default.aspx (accessed on 30 September 2019).

62. Bosso, S.T.; Enzweiler, J. Bioaccessible lead in soils, slag, and mine wastes from an abandoned mining district in Brazil. Environ. Geochem. Health 2008, 30, 219-229. [CrossRef] [PubMed]

63. Fernandas, H.M.; Veiga, L.H.S.; Franklin, M.R.; Prado, V.C.S.; Taddei, J.F. Environmental impact assessment of uranium mining and milling facilities: A study case at the poços de caldas uranium mining and milling site, Brazil. J. Geochemical Explor. 1995, 52, 161-173. [CrossRef]

64. Galhardi, J.A.; Bonotto, D.M. Hydrogeochemical features of surface water and groundwater contaminated with acid mine drainage (AMD) in coal mining areas: A case study in southern Brazil. Environ. Sci. Pollut. Res. 2016, 23, 18911-18927. [CrossRef] [PubMed]

65. Perlatti, F.; Ferreira, T.O.; da Costa Roberto, F.A.; Romero, R.E.; Sartor, L.R.; Otero, X.L. Trace metal/metalloid concentrations in waste rock, soils and spontaneous plants in the surroundings of an abandoned mine in semi-arid NE-Brazil. Environ. Earth Sci. 2015, 74, 5427-5441. [CrossRef]

66. Novo, L.A.B.; Covelo, E.F.; González, L. The use of waste-derived amendments to promote the growth of Indian mustard in copper mine tailings. Miner. Eng. 2013, 53, 24-30. [CrossRef]

67. Asensio, V.; Covelo, E.F.; Kandeler, E. Soil management of copper mine tailing soils—Sludge amendment and tree vegetation could improve biological soil quality. Sci. Total Environ. 2013, 456-457, 82-90. [CrossRef]

68. Fernández-Calviño, D.; Pérez-Armada, L.; Cutillas-Barreiro, L.; Paradelo-Núñez, R.; Núñez-Delgado, A.; Fernández-Sanjurjo, M.J.; Álvarez-Rodriguez, E.; Arias-Estévez, M. Changes in Cd, Cu, Ni, Pb and Zn Fractionation and Liberation Due to Mussel Shell Amendment on a Mine Soil. L. Degrad. Dev. 2016, 1285, 1276-1285. [CrossRef]

69. Lebrun, M.; Miard, F.; Nandillon, R.; Scippa, G.S.; Bourgerie, S.; Morabito, D. Biochar effect associated with compost and iron to promote $\mathrm{Pb}$ and As soil stabilization and Salix viminalis L. growth. Chemosphere 2019, 222, 810-822. [CrossRef]

(C) 2020 by the authors. Licensee MDPI, Basel, Switzerland. This article is an open access article distributed under the terms and conditions of the Creative Commons Attribution (CC BY) license (http://creativecommons.org/licenses/by/4.0/). 